\title{
Use of Duddingtonia flagrans in the control of gastrointestinal nematodes of feedlot goats
}

\section{Utilização de Duddingtonia flagrans no controle dos nematódeos gastrintestinais de caprinos mantidos em confinamento}

\author{
Vinícius Longo Ribeiro Vilela ${ }^{1 *}$; Thais Ferreira Feitosa ${ }^{1}$; Fabio Ribeiro Braga ${ }^{2}$; \\ Antonielson dos Santos ${ }^{3}$; Roberto Alves Bezerra ${ }^{3}$; Gabriela Lucena Longo Silva ${ }^{4}$; \\ Ana Célia Rodrigues Athayde ${ }^{5}$ Jackson Victor de Araújo ${ }^{6}$
}

\author{
Highlights: \\ D. flagrans was effective on gastrointestinal helminthiases of feedlot goats. \\ D. flagrans group had better PCV values. \\ D. flagrans group had EPG reduction of $92.3 \%$. \\ D. flagrans group showed a final mean weight gain of $8.8 \mathrm{~kg}$.
}

\begin{abstract}
This study aimed to evaluate the use of a sodium alginate matrix-pelletized formulation of Duddingtonia flagrans for biological control of gastrointestinal nematodiasis in feedlot goats in the semiarid region of Northeastern Brazil. We used 20 Saanen female goats (age, 4 months; average weight, $12 \mathrm{~kg}$ ) that did not receive anthelmintic treatment and had counting of eggs per gram of faeces (EPGs) $\geq 500$. The animals were divided into two groups: in group 1 (D. flagrans group), each animal received $3 \mathrm{~g}$ of pellets ( $0.6 \mathrm{~g}$ of $D$. flagrans mycelium) per $10 \mathrm{~kg}$ of body weight, twice a week, over 4 months; and in group 2 (control group), each animal received $3 \mathrm{~g}$ of pellets without fungus per $10 \mathrm{~kg}$ of body weight, twice a week, over 4 months. Each group was maintained in a separate $15-\mathrm{m}^{2}$ stall. Larval cultures and measurements of weight, EPG, and packed cell volume (PCV) were performed every 15 days. We observed low EPG levels in the $D$. flagrans group throughout the experimental period, with a significant difference $(p<0.05)$ on day 30 and from day 60 , having, at the end of the experiment, average OPG values of only 150 , reduction of $92.3 \%$ when compared to control group. Haemonchus sp. was the most prevalent helminth in all larval cultures. The $D$. flagrans group showed a mean weight gain of $8.8 \mathrm{~kg}$ at the end of the experiment $(p<0.05)$, while the control group showed a mean weight gain of $4.8 \mathrm{~kg}$. The best PCV results $(p<0.05)$ were also observed in the D. flagrans group from day 30 . Thus, the use of D. flagrans pellets in a sodium alginate matrix was effective in controlling gastrointestinal nematodiasis of feedlot goats in the semiarid region of Northeastern Brazil.
\end{abstract}

Key words: Farming goat. Biological control. Haemonchus sp. Helminthiasis.

\footnotetext{
Profs., Departamento de Medicina Veterinária, Instituto Federal da Paraíba, IFPB, Sousa, PB, Brasil. E-mail: vinicius.vilela@, ifpb.edu.br; thais.feitosa@ifpb.edu.br

2 Prof., Programa de Pós-Graduação em Ciência Animal, Universidade Vila Velha, UVV, Vila Velha, ES, Brasil. E-mail: fabioribeirobraga@hotmail.com

3 Discentes, Departamento de Medicina Veterinária, IFPB, Sousa, PB, Brasil. E-mail: antonielsonvet@gmail.com; roberto. alvesbezerra11@gmail.com

4 Pesquisadora, Programa de Pós-Graduação em Ciência Animal, Universidade Federal de Campina Grande, UFCG, Patos, PB, Brasil. E-mail: gabrielalongovet@gmail.com

5 Prof ${ }^{a}$, Unidade Acadêmica de Ciências Biológicas, UFCG, Patos, PB, Brasil. E-mail: athayde@cstr.ufcg.edu.br

6 Prof., Departamento de Veterinária, Universidade Federal de Viçosa, UFV, Viçosa, MG, Brasil.E-mail: jvictor@ufv.br

* Author for correspondence
} 


\title{
Resumo
}

\begin{abstract}
Objetivou-se avaliar a utilização da formulação peletizada em matriz de alginato de sódio de Duddingtonia flagrans no controle biológico das nematodeoses gastrintestinais de caprinos mantidos em confinamento no semiárido do Nordeste brasileiro. Foram utilizados 20 caprinos da raça Saanen, fêmeas, com quatro meses de idade, média de peso de $12 \mathrm{~kg}$, sem tratamento anti-helmíntico prévio e com contagem de ovos por grama de fezes $(\mathrm{OPG}) \geq 500$. Os animais foram divididos em dois grupos: grupo 1 , cada animal recebeu na ração $3 \mathrm{~g}$ de péletes $(0,6 \mathrm{~g}$ de micélio fúngico de $D$. Alagrans $)$ para cada $10 \mathrm{~kg}$ de peso vivo, duas vezes por semana, durante quatro meses; grupo 2, cada animal recebeu na ração $3 \mathrm{~g}$ de péletes sem fungos para cada $10 \mathrm{~kg}$ de peso vivo, duas vezes por semana, durante quatro meses, servindo como grupo controle. Cada grupo permaneceu em uma baia de $15 \mathrm{~m}^{2}$. Foram realizadas contagens de OPG, determinação de volume globular (VG), coproculturas e pesagem dos animais a cada 15 dias. Observaram-se baixos valores de OPG no grupo $D$. flagrans durante todo o experimento, com diferença significativa $(\mathrm{p}<0,05)$ no dia 30 e a partir do dia 60 , tendo, ao final do experimento, valores médios de OPG de apenas 150. No grupo Controle, a contagem final foi de 1950 OPG. Haemonchus sp. foi o gênero de helminto mais prevalente em todas as coproculturas. O grupo $D$. flagrans apresentou média de ganho de peso de $8,8 \mathrm{~kg}$ ao final do experimento e o grupo Controle, 4,8 $\mathrm{kg}(\mathrm{p}<0,05)$. Também foram observados os melhores índices de VG $(\mathrm{p}<0,05)$ no grupo D. flagrans a partir do dia 30. Concluiu-se que a utilização de péletes em matriz de alginato de sódio de $D$. flagrans foi eficaz no controle das nematodeoses gastrintestinais de caprinos mantidos em confinamento no semiárido do Nordeste brasileiro.
\end{abstract}

Palavras-chave: Caprinocultura. Controle biológico. Haemonchus sp. Verminose.

\section{Introduction}

Goat farming is an activity of great importance in Northeastern Brazil, mainly in the semiarid region, where goat meat is considered the main source of animal protein. Although numerical expressive, goat herds show low productive indexes because of several factors, including infections by gastrointestinal helminths (Salgado, \& Santos, 2016). In the semiarid, there are a predominant goat production in small farms, where feedlot dairy goats are raised in confinement, in precarious facilities characterized by free housing in concrete flooring (Riet-Correa et al., 2013). Another frequent problem is food and water contamination with feces, due to the inadequate positioning of feeders and drinking fountains, which are not placed on the external side, favoring the occurrence of neonatal infections, coccidiosis and gastrointestinal helminthiasis (Patil, 2010).

Moreover, due to the producers' lack of technical information, the indiscriminate use of anthelmintics has resulted in the development of resistance to the various molecules available in the market, as ivermectin, moxidectin, levamisole, albendazole, closantel and monepantel, causing major problems in the control of helminthiasis in goats and sheep in the Brazilian semiarid region (Lima et al., 2010; Vieira et al., 2014; F. F. Silva, Bezerra, Feitosa, \& Vilela, 2018).

In this context, multiple efforts have been made to identify alternative agents capable of controlling gastrointestinal helminths in small ruminants. The use of nematophagous fungi in sodium alginatebased formulations is a promising option for in vitro and in vivo control of parasites of various domestic animal species, including goats, by producing traps that capture and fix nematodes by destroying their internal organs (Paraud, Pors, \& Chartier, 2007; Braga et al., 2009; A. R. Silva, Araújo, Braga, Alves, \& Frassy, 2011; Vilela et al., 2013; Silveira et al., 2017). Fungi pelleted in sodium alginate can be kept in stock and are made from inert materials, allowing their use mixed in food supplement supplied to herds. The orally administered pellets are eliminated in the faeces for up to 120 hours (J. 
V. Araújo, 2009). The decrease in the larvae caused by administration of nematophagous fungi prevents clinical parasitism, reducing reinfection of the animals in the pasture and allowing them to develop natural immunity against nematodes (J. V. Araújo, Gomes, \& Guimarães, 1998).

Duddingtonia flagrans is the most studied and is considered the most promising species for the control of gastrointestinal helminths of domestic animals (Larsen, Faedo, Waller, \& Hennessy, 1998; Faedo et al., 2002). In addition, it has been used successfully for field control of parasitic helminths of production animals (Braga \& Araújo, 2014). Feedlot goats constantly require anthelmintic treatment because they are more susceptible to reinfections by larvae of gastrointestinal parasites, usually by direct and permanent contact with the feces. However, there are no studies evaluating the action of nematophagous fungi in controlling reinfection among confined animals in non-slatted floor.

The objective of this study was to evaluate the use of a pelleted formulation composed of D. flagrans in a sodium alginate matrix for the biological control of gastrointestinal nematodes of confined goats in the semiarid state of Paraíba, Northeast Brazil.

\section{Materials and Methods}

\section{Fungi and production of mycelial mass}

An isolate of the nematode predator fungus $D$. flagrans (AC001) was used for the experiment. This isolate was obtained from soils from the Zona da Mata region of the State of Minas Gerais, Brazil, and has been stored at the parasitology laboratory of the Universidade Federal de Viçosa, MG, Brazil.

The fungal mycelia were obtained by transferring culture disks (approximately $4 \mathrm{~mm}$ in diameter) of the fungal isolates (D. flagrans) in $2 \%$ agarwater ( $2 \% \mathrm{AA})$ to $250-\mathrm{ml}$ Erlenmeyer flasks with $150 \mathrm{ml}$ of GPY liquid medium (glucose, sodium peptone and yeast extract), followed by incubation at $26{ }^{\circ} \mathrm{C}$ and $120 \mathrm{rpm}$ in the dark for 10 days. After this period, the mycelia were removed, filtered, and weighed in a precision analytical balance. All procedures followed the methodology proposed by J. M. Araújo, Araújo, Braga and Carvalho (2010).

\section{Experimental and animal testing}

The experiment was carried out at a farm in the city of Patos, Paraíba, Northeast Brazil, latitude $7^{\circ} 1$ '2 $8^{\prime \prime}$ S, longitude $37^{\circ} 16^{\prime} 48^{\prime \prime} \mathrm{W}$, from February to May 2015. To simulate the characteristic facilities of the semiarid region, as described by Riet-Correa et al. (2013), the experiment was carried out in a shed with two stalls of $15 \mathrm{~m}^{2}$ each. The stalls had concrete flooring, roofing with clay tiles, troughs, and drinking fountains. They underwent complete sanitation every 15 days, during which the bed composed of wood shavings was completely replaced and the floors and walls were washed and disinfected with $1 \%$ sodium hypochlorite. An experimental group was allocated to each stall.

In order to select the anthelmintic to be used, 18 goats were divided into three groups and underwent the faecal egg count reduction (FECR) test according to the method described by Coles et al. (1992). The anthelmintics orally used were moxidectin $0.2 \%$ - Cydectin ora ${ }^{\circledR} /$ Fort Dodge $(0.5 \mathrm{mg} / \mathrm{kg}$ body weight), ivermectin $0.08 \%$ - Ivomec ovino ${ }^{\circledR /}$ Merial $(0.2 \mathrm{mg} / \mathrm{kg}$ body weight), and levamisole hydrochloride 5\% - Ripercol ${ }^{\circledR} /$ Fort Dodge $(5 \mathrm{mg} /$ $\mathrm{kg}$ body weight), which showed a higher FECR (91\%) and was chosen for the study.

Twenty female Saanen goats (age, 4 months; mean weight, $12 \pm 1.93 \mathrm{~kg}$ ) that had not received anthelmintic treatment previously and had egg counts per gram of faeces (EPGs) $\geq 500$ were used. The animals were divided into two groups: group 1 (D. flagrans group), in which each animal received $3 \mathrm{~g}$ of pellets containing $0.6 \mathrm{~g}$ of $D$. flagrans mycelia per $10 \mathrm{~kg}$ of body weight twice a week for four months; and group 2 (control group), in which each animal received $3 \mathrm{~g}$ of fungus-free pellets per $10 \mathrm{~kg}$ 
of body weight twice a week for four months (A. R. Silva et al., 2011; Silveira et al., 2017).

The animals received a complete diet based on corn and soybean meal, amount equivalent to $1.5 \%$ of live weight, as well as hay of Tifton (Cynodon dactylon) grass and a complete mineral mixture and water ad libitum, in order to meet the nutritional requirements for sheep according to National Research Council [NRC] (1985).

To prevent mortality, salvage anthelmintic treatments were performed individually when the animals had a packed cell volume (PCV) of less than $16 \%$; the dewormer used was levamisole hydrochloride ( $5 \mathrm{mg} / \mathrm{kg}$ body weight).

Faecal and blood collection were performed every 15 days for EPG analyses (Gordon \& Whitlock, 1939), coprocultures (Roberts \& O'Sullivan, 1950), and PCV measurements (Ferreira, Viana, \& Magalhães, 1981). Every 15 days, the animals were also weighed to monitor development.

The specialized station of the Federal University of Campina Grande, Patos-PB campus, supplied the meteorological data such as temperature, relative humidity and rainfall. During the experiment, the temperature varied from $26{ }^{\circ} \mathrm{C}$ to $36{ }^{\circ} \mathrm{C}$, the relative air humidity from $51 \%$ to $88 \%$ and the monthly rainfall was $70 \mathrm{~mm}$ in June 2015 and $45 \mathrm{~mm}$ in JulySeptember 2015.

The study was approved by the Animal Care and Ethics Committee, Federal University of Campina Grande, Patos, Paraíba, Brazil (Approval number: 23000,000525,2015/13).

\section{Statistical analysis}

Data were assessed with one-way analysis of variance (ANOVA) and test t 5\% probability. The EPG values were analysed using $\log (\mathrm{x}+1)$ logarithmic transformation; however, they are presented in the figures as arithmetic means of the untransformed values. The analyses were performed using BioEstat 5.0 Software (Ayres, Ayres, Ayres, \& Santos, 2003).

\section{Results}

The D. flagrans group showed low EPG values during the entire experiment, with a statistically significant difference $(p<0.05)$ in comparison with the control group on day 30 and from day 60 (Figure 1). At the end of the experiment, the EPG value in the $D$. Alagrans group was only $150 \pm 135$, whereas that in the control group was $1950 \pm 955$.

No animals of the D. flagrans group required salvage anthelmintic treatment. However, in the control group, four goats were dewormed: two on day 45 and two on day 60 .

The most prevalent helminth in all coprocultures was Haemonchus sp., followed by Trichostrongylus spp., Strongyloides sp., and Oesophagostomum sp. (Table 1).

There was a significant statistical difference ( $p$ $<0.05$ ) between the groups in relation to the weight gain from day 90 (Figure 2). The D. flagrans group had a mean weight gain of $8.8 \pm 1.46 \mathrm{~kg}$ throughout the experiment. In the control group, the mean weight gain was $4.8 \pm 0.91 \mathrm{~kg}$. 
D. flagrans Control

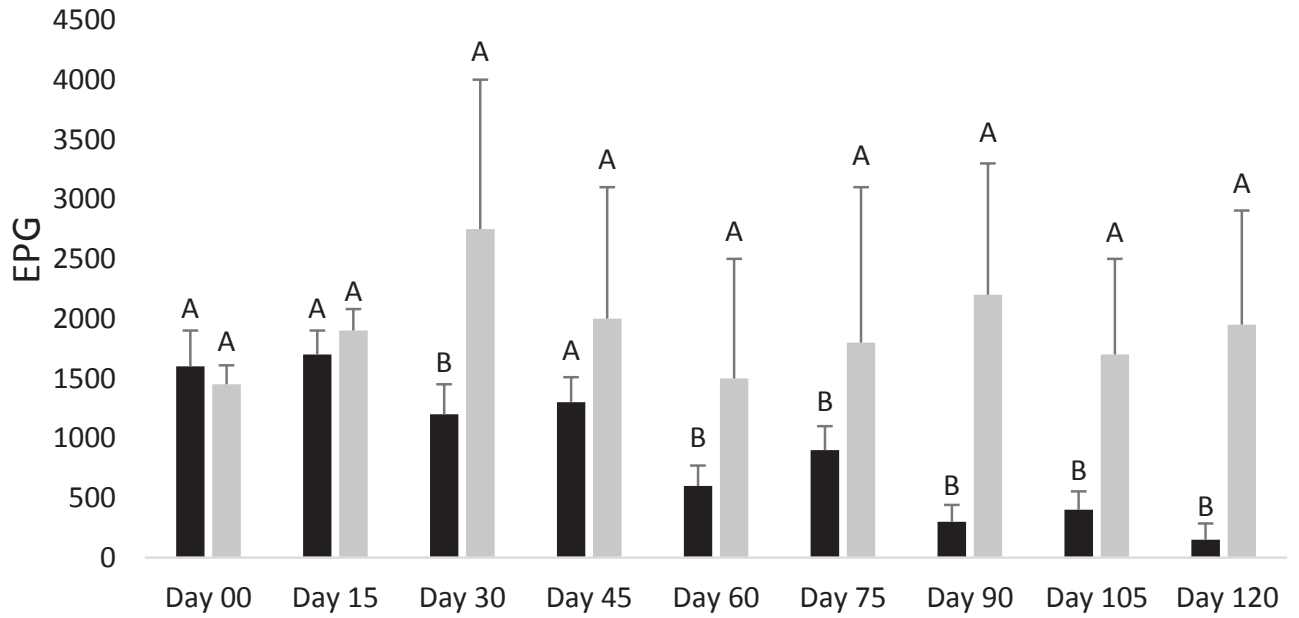

Figure 1. Monthly means and standard deviations of egg counts per gram of faeces (EPG) of goats of the D. flagrans $(0.6 \mathrm{~g} / 10 \mathrm{~kg}$ body weight, twice a week) and control groups kept in confinement for 120 days in the Northeastern semiarid region. The values followed by equal letters are statistically similar $(p>0.05)$-Tukey's test at $5 \%$.

Table 1

Percentage of infecting larvae of Haemonchus sp. (H), Trichostrongylus spp. (T), Strongyloides sp. (S), and Oesophagostomum sp. (O) in coprocultures of goats treated with $D$. flagrans and control group, kept in confinement for 120 days in the Semiarid region of Northeastern Brazil

\begin{tabular}{ccccccccccc}
\hline \multirow{2}{*}{ Groups } & \multicolumn{10}{c}{ Days } \\
\cline { 2 - 11 } D. flagrans & & 00 & 15 & 30 & 45 & 60 & 75 & 90 & 105 & 120 \\
\hline \multirow{5}{*}{ Control } & $\mathrm{H}$ & 89 & 89 & 92 & 88 & 90 & 81 & 76 & 88 & 91 \\
& $\mathrm{~T}$ & 10 & 6 & 4 & 8 & 6 & 12 & 16 & 7 & 8 \\
& $\mathrm{~S}$ & 1 & 5 & 3 & 2 & 4 & 3 & 5 & 4 & 1 \\
& $\mathrm{O}$ & - & - & 1 & 2 & - & 4 & 3 & 1 & - \\
& $\mathrm{H}$ & 88 & 93 & 92 & 88 & 90 & 86 & 89 & 83 & 82 \\
& $\mathrm{~T}$ & 11 & 4 & 5 & 6 & 7 & 10 & 9 & 11 & 12 \\
& $\mathrm{~S}$ & - & 3 & 2 & 4 & 3 & 3 & 2 & 4 & 3 \\
\hline
\end{tabular}




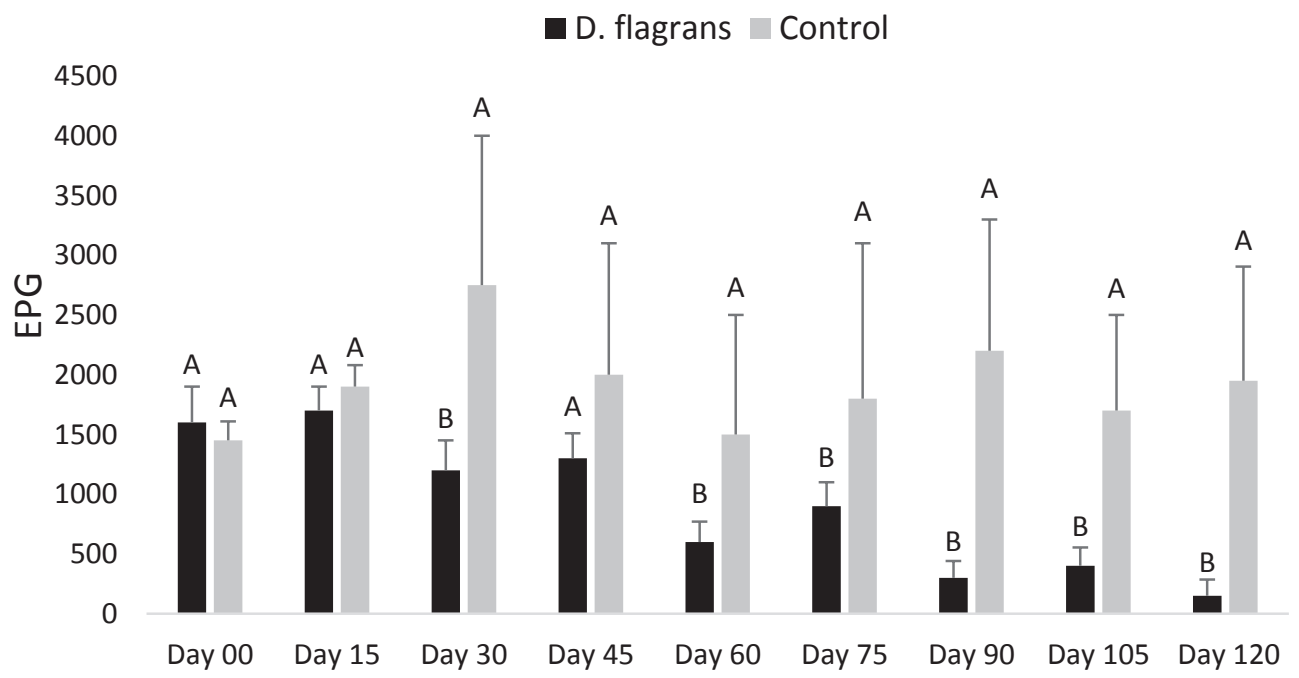

Figure 2. Monthly means and standard deviations of the weight $(\mathrm{kg})$ of goats in the $D$. flagrans $(0.6 \mathrm{~g} / 10 \mathrm{~kg}$ of live weight, twice a week) and control groups kept in confinement for 120 days in the Northeastern semiarid region. The values followed by equal letters are statistically similar $(p>0.05)$ - Tukey's test at $5 \%$.

The groups differed significantly $(p<0.05)$ in 105 , and 120. The best PCV indices were observed relation to the percentage of PCV on days 30,45,75, in D. flagrans group (Figure 3).

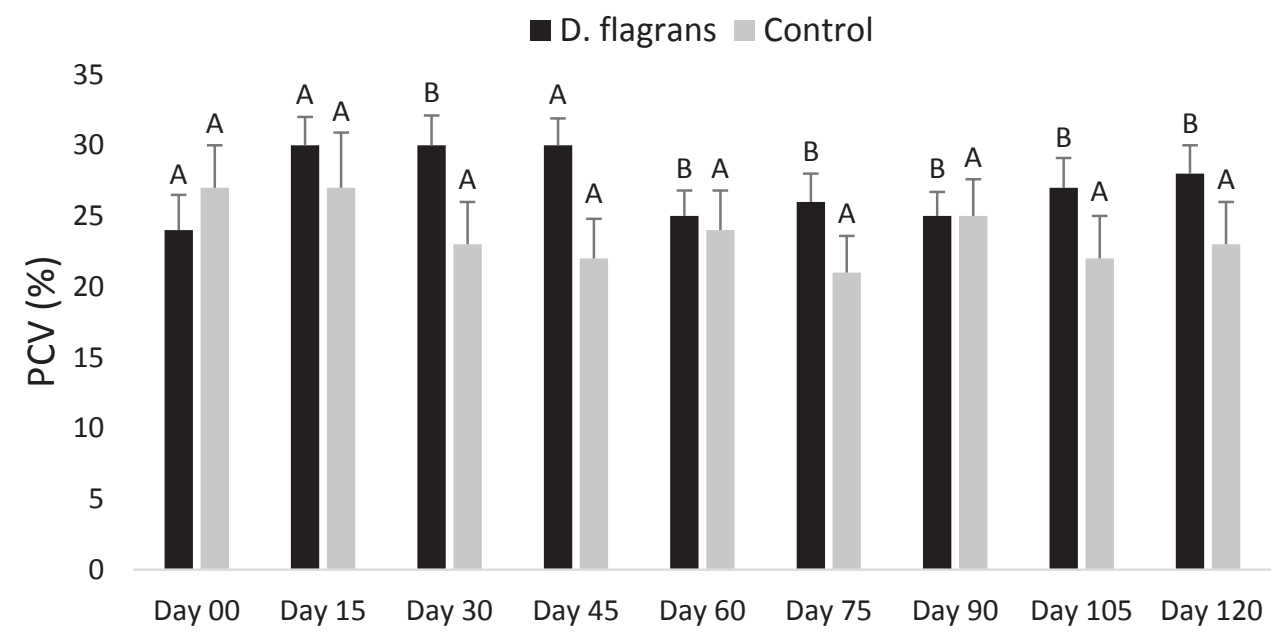

Figure 3. Monthly means and standard deviations of the packed cell volume (PCV) of goats in D. flagrans $(0.6 \mathrm{~g} / 10 \mathrm{~kg}$ of live weight, twice a week) and control groups kept in confinement for 120 days in the Northeastern semiarid region. The values followed by equal letters are statistically similar $(p>0.05)$-Tukey's test at $5 \%$.

\section{Discussion}

The $D$. flagrans group showed low EPG values throughout the experiment $(p<0.05)$, with the parasite load on day 120 being $92 \%$ lower than that in the control group. A reduction in small ruminant EPG, although lower than that noted in the present study, was observed by Vilela et al. (2012), Vilela et al. (2013), Vilela et al. (2016) and Vilela et al. (2018) after the use of pellets of nematophagous fungi in 
the Northeastern semiarid region. However, these animals were kept in an extensive regime and fed on pasture native to the Caatinga, which increased reinfection rates.

Since the parasitic load of the D. flagrans group remained low throughout the experiment, no salvage anthelmintic treatment was required for these animals. On the other hand, four animals in the control group required anthelmintic treatment when they showed PCV $\leq 16 \%$.

Haemonchus sp. was the most frequently observed helminth genus in the coprocultures. According to Vieira et al. (2014), who studied the prevalence of goat gastrointestinal helminths in the Paraíba semiarid region, the genus Haemonchus sp., represents $83.2 \%$ of the helminth fauna of the animals. In tropical countries, Haemonchus contortus is the most prevalent nematode in herds, causing severe losses due to the high pathogenic pressure it exerts through hematophagy (Kassai, 1999).

From day 90, the D. flagrans group showed better weight gain, with a mean gain of $8.8 \mathrm{~kg}$ at the end of the experiment. In the control group, the mean weight gain was $4.8 \mathrm{~kg}$. Studies by J. V. Araújo, Rodrigues, Silva and Vieira (2007), Vilela et al. (2012), and Vilela et al. (2016) also reported higher weight gain in groups of small ruminants receiving pelleted formulations of sodium alginate matrix containing nematophagous fungi in the Brazilian semiarid region. Due to the reduced reinfection rates in the animals, they were able to overcome preexisting helminth infections, thereby increasing weight gain.

The $D$. flagrans group showed better PCV indices from day 30 . Similar results were observed by Vilela et al. (2012), who reported better PCV percentages 60, 90, and 120 days after administration of $D$. flagrans pellets to goats. However, B. F. Silva et al. (2010) did not find a significant statistical difference in PCV in sheep that received D. flagrans pellets in Southeastern Brazil.
Animals kept in confinement in poorly sanitized stalls with concrete flooring constantly require anthelmintic treatment, even when they receive pasture that is free of $\mathrm{L}_{3}$ gastrointestinal nematodes, since these conditions favour the addition of moisture in the faeces through the urine of the animals, which facilitates the development of $\mathrm{L}_{3}$ parasites and allows reinfection.

The use of the pelleted formulation of D. flagrans in a sodium alginate matrix could reduce reinfection by predation of $\mathrm{L}_{3}$ parasites in the environment, which in this case was the stall of the D. flagrans group. This approach reduced the parasitic load to the point where no salvage anthelmintic treatment was needed, which directly led to better PCV indices and weight gain.

\section{Conclusion}

The findings show that the sodium alginate matrixpelleted formulation of $D$. flagrans was effective in achieving biological control of gastrointestinal nematodes in goats kept in confinement in the Brazilian Northeast semiarid region.

\section{Acknowledgment}

The authors would like to thank the Coordenação de Aperfeiçoamento de Pessoal de Nível Superior (CAPES), the Fundação de Amparo à Pesquisa de Minas Gerais (FAPEMIG) and the Fundação de Amparo à Pesquisa do Espirito Santo (FAPES) for the financial support.

\section{References}

Araújo, J. M., Araújo, J. V., Braga, F. R., \& Carvalho, R. O. (2010). In vitro predatory activity of nematophagous fungi and after passing through gastrointestinal tract of equine on infective larvae of Strongyloides westeri. Parasitology Research, 107(1), 103-108. doi: 10.1007/s00436-010-1841-y

Araújo, J. V., Gomes, A. P. S., \& Guimarães, M. P. (1998). Biological control of bovine gastrointestinal 
nematode parasites in Southern Brazil by nematodetrapping fungus Arthrobotrys robusta. Revista Brasileira de Parasitologia Veterinária, 7(2), 117122.

Araújo, J. V., Rodrigues, M. L. A., Silva, W. W., \& Vieira. L. S. (2007). Controle biológico de nematóides gastrintestinais de caprinos em clima semi-árido pelo fungo Monacrosporium thaumasium. Pesquisa Agropecuária Brasileira, 42(8), 1177-1181. doi: 10.1590/S0100-204X2007000800015

Araújo, J. V. (2009). Controle biológico. In: A. C. R. Cavalcante, L. S. Vieira, A. C. S. Chagas, \& M. B. Molento (Eds.). Doenças parasitárias de caprinos e ovinos: epidemiologia e controle (pp. 401-426). Brasília: Embrapa.

Ayres, M., Ayres, J. R. M., Ayres, D. L., \& Santos, A. S. (2003). Aplicações estatísticas nas áreas de ciências biológicas e médicas. Belém: Sociedade Civil Mamirauá, Brasília: CNPq.

Braga, F. R., \& Araújo, J. V. (2014). Nematophagous fungi for biological control of gastrointestinal nematodes in domestic animals. Journal Applied Microbiology, 98(1), 71-82. doi: 10.1007/s00253-013-5366-z

Braga, F. R., Araújo, J. V., Silva, A. R., Araújo, J. M., Carvalho, R. O., Tavela, A. O., . . Carvalho, G. L. (2009). Biological control of horse cyathostomin (Nematoda: Cyathostominae) using the nematophagous fungus Duddingtonia flagrans in tropical southeastern Brazil. Veterinary Parasitology, 163(4), 335-340. doi: 10.1016/j.vetpar.2009.05.003

Coles, G. C., Bauer, C., Borgsteede, F. H., Geerts, S., Klei, T. R., Taylor, M. A., \& Waller, P. J. (1992). World Association for the Advancement of Veterinary Parasitology (WAAVP) methods for the detection of anthelmintic resistance in nematodes of veterinary importance. Veterinary Parasitolology, 44(1-2), 3544. doi:

Faedo, M., Larsen, M., Dimander, S. O., Yates, G. W., Hoglund, J., \& Waller, P. J. (2002). Growth of the fungus Duddingtonia flagrans in soil surrounding feces deposited by cattle or sheep fed the fungus to control nematode parasites. Biological Control, 23(1), 64-70. doi: 10.1006/bcon.2001.0987

Ferreira, J. M., Neto, Viana, E. S., \& Magalhães, L. M. (1981). Patologia clínica veterinária. Belo Horizonte: Rabelo.

Gordon, H. M., \& Whitlock, H. V. (1939). A new technique for counting nematode eggs in sheep faeces. Journal of the Council for Scientific and Industrial Research, 12(1), 50-52.
Kassai, T. (1999). Veterinary Helminthology. Oxford: Butterworth \& Heineann.

Larsen, M, Faedo, M., Waller, P. J., \& Hennessy, D. R. (1998). The potencial of nematophagous fungi to control the free living stages of nematode parasites of sheep: studies with Duddingtonia flagrans. Veterinary Parasitology, 76(1-2), 121-128. doi: 10.1016/S0304-4017(97)00056-3

Lima, W. C., Athayde, A. C. R., Medeiros, G. R., Lima, D. A. S. D., Borburema, J. B., Santos, E. M., . . . Azevedo, S. S. (2010). Nematóides resistentes a alguns anti-helmínticos em rebanhos caprinos no Cariri paraibano. Pesquisa Veterinária Brasileira, 30(12), 1002-1009. doi: 10.1590/S0100736X2010001200001

National Research Council. (1985). Nutrient requirements of domestics animals: nutrient requeriments of sheep. Washington: National Academy Press.

Paraud, C., Pors, I., \& Chartier, C. (2007). Efficiency of feeding Duddingtonia flagrans chlamydospores to control nematode parasites of first-season grazing goats in France. Veterinary Research Communications, 31(3), 305-317. doi: 10.1007/ s11259-006-3467-1

Patil, V. M. (2010). Housing systems, layout and design of different buildings for sheep and goat farms. Bidar: Katti Tugaon. Retrieved from https://sites.google. $\mathrm{com} /$ site/viveklpm/sheep-and-goat-productionmanagement/housing-systems-layout-and-designof-different-buildings-for-sheep-and-goat-farms

Riet-Correa, B., Simões, S. V. D., Pereira, J. M., F ${ }^{\circ}$, Azevedo, S. S., Melo, D. B., Batista, J. A., . . . Riet-Correa, F. (2013). Sistemas produtivos de caprinocultura leiteira no semiárido paraibano: caracterização, principais limitantes e avaliação de estratégias de intervenção. Pesquisa Veterinária Brasileira, 33(3), 345-352. doi: 10.1590/S0100736X2013000300012

Roberts, F. H. S., \& O'Sullivan, J. P. (1950). Methods of egg counts and larval cultures for strongyles infesting the gastrointestinal tract of cattle. Australian Journal of Agricultural Research, 1(1), 99-102.

Salgado, J. A., \& Santos, C. P. (2016). Overview of anthelmintic resistance of gastrointestinal nematodes of small ruminants in Brazil. Revista Brasileira de Parasitologia Veterinária, 25(1), 3-17. doi: 10.1590/ S1984-29612016008

Silva, A. R., Araújo, J. V., Braga, F. R., Alves, C. D. F., \& Frassy, L. N. (2011). Activity of fungal conidia of the Duddingtonia flagrans and Monacrosporium 
thaumasium on Haemonchus contortus infective larvae. Journal of Helminthology, 85(2), 138-141. doi: 10.1017/S0022149X10000362

Silva, B. F., Carrijo-Mauad, J. R., Braga, F. R., Campos, A. K., Araújo, J. V., \& Amarante, A. F. T. (2010). Efficacy of Duddingtonia flagrans and Arthobotrys robusta in controlling sheep parasitic gastroenteritis. Parasitology Research, 106(6), 1343-1350. doi: 10.1007/s00436-010-1805-2

Silva, F. F., Bezerra, H. M. F. F., Feitosa, T. F., \& Vilela, V. L. R. (2018). Nematode resistance to five anthelmintic classes in naturally infected sheep herds in Northeastern Brazil. Revista Brasileira de Parasitologia Veterinária, 27(4), 423-429. doi: 10.1590/s1984-296120180071

Silveira, W. F., Oliveira, G. D., Silva, L. A., Carvalho, L. M., Braga, F. R., Zanuncio, J. C., \& Araújo, J. V. (2017). Predation rate of nematophagous fungi after passing through the gastrointestinal tract of goats. Small Ruminant Research, 147, 101-105. doi: 10.1016/j.smallrumres.2016.12.025

Vieira, V. D., Feitosa, T. F., Vilela, V. L. R., Azevedo, S. S., Almeida, J. L., Neto, Morais, D. F., . . . Athayde, A. C. R. (2014). Prevalence and risk factors associated with goat gastrointestinal helminthiasis in the Sertão region of Paraíba State, Brazil. Tropical Animal Health and Production, 46(2), 355-361. doi: 10.1007/s11250-013-0496-y
Vilela, V. L. R., Feitosa, T. F., Braga, F. R., Araújo, J. V., Lucena, S. C., Dantas, E. S., . . S Silva, W. W. (2013). Efficacy of Monacrosporium thaumasium in the control of goat gastrointestinal helminthiasis in a semi-arid region of Brazil. Parasitology Research, 112(2), 871-877. doi: 10.1007/s00436-012-3078-4

Vilela, V. L. R., Feitosa, T. F., Braga, F. R., Araújo, J. V., Santos, A., Morais, D. F., . . Athayde, A. C. R. (2016). Coadministration of nematophagous fungi for biological control over gastrointestinal helminths in sheep in the semiarid region of northeastern Brazil. Veterinary Parasitology, 221, 139-143. doi: 10.1016/j.vetpar.2016.03.027

Vilela, V. L. R., Feitosa, T. F., Braga, F. R., Araújo, J. V., Souto, D. V.O., Santos, H. E.S., . . Athayde, A. C.R. (2012). Biological control of goat gastrointestinal helminthiasis by Duddingtonia flagrans in a semiarid region of the northeastern Brazil. Veterinary Parasitology, 188(1-2), 127-133. doi: 10.1016/j. vetpar.2012.02.018

Vilela, V. L. R., Feitosa, T. F., Braga, F. R., Vieira, V. D., Lucena, S. C. D., \& Araújo, J. V. (2018). Control of sheep gastrointestinal nematodes using the combination of Duddingtonia flagrans and Levamisole Hydrochloride 5\%. Revista Brasileira de Parasitologia Veterinária, 27(1), 26-31. doi: 10.1590/s1984-296120180011

Vilela, V. L. R., Solano, G. B., Araújo, M. M., Sousa, R. V. R., Silva, W. A. S., Feitosa, T. F., \& Athayde, A. C. R. (2008). Ensaios preliminares para a validação do Método FAMACHA ${ }^{\odot}$ em condições de semiárido paraibano. Revista Brasileira de Parasitologia Veterinária, 17(1), 164-167. 
